\title{
The Relationship Between Family History and Dietary Patterns to the Incidence of Diabetes Mellitus in Ledug, Kembaran, Banyumas, Central Java, Indonesia
}

\author{
$1^{\text {st }}$ Etika Dewi Cahyaningrum, \\ D3 Midwifery Study Program, Health Faculty \\ Harapan Bangsa University \\ tita.etika@gmail.com
}

\author{
$2^{\text {nd }}$ Rosi Kurnia Sugiharti \\ D3 Midwifery Study Program, Health Faculty \\ Harapan Bangsa University \\ rosikurnia@uhb.ac.id
}

\begin{abstract}
Diabetes mellitus (DM) is a disease caused by metabolic disorders that occur in the pancreas which are characterized by an increase in blood sugar or often referred to as hyperglycemia due to a decrease in the amount of insulin from the pancreas (American Diabetes Association, 2012). The most common type of diabetes mellitus is type 2 diabetes. One of the irreversible risk factors for diabetes mellitus is family history, and one of the reversible risk factors is dietary patterns. This study aimed to determine the relationship between family history and dietary patterns to the incidence of diabetes mellitus. A correlational analysis with a crosssectional approach was applied in this study. The sampling technique used was simple random sampling. The samples of this study were members of Chronic Disease Management Program (Prolanis) in Ledug, Kembaran, Banyumas in June 2019. The samples were 480 respondents determined by the Slovin's formula. The type of data was the primary data obtained from questionnaire as the measurement instrument. The data analysis used was univariate frequency distribution and ChiSquare bivariate analysis. The results showed that there was no relationship between family history and the incidence of diabetes mellitus, but there was a relationship between dietary patterns and the incidence of diabetes mellitus.
\end{abstract}

Keywords: family history, dietary patterns, diabetes mellitus

\section{INTRODUCTION}

Non-communicable diseases are the leading cause of death in the world. The WHO data shows that of the 57 million deaths occurred globally in 2008, 36 million or almost two-thirds were caused by non-communicable diseases. More than two-thirds (70\%) of the world's population will die from non-communicable diseases such as cancer, heart disease, stroke, and diabetes. The prevalence of non-communicable diseases in 2018 increased compared to the previous data in 2013, including cancer, stroke, chronic kidney disease, diabetes mellitus, and hypertension. Based on blood glucose tests, diabetes mellitus has risen from $6.9 \%$ to $8.5 \%$. The increase in the prevalence of noncommunicable diseases is related to lifestyles, such as physical activity, and consumption of fruits and vegetables [1]. One of noncommunicable diseases that deserves attention is diabetes mellitus, a disease caused by metabolic disorders that occur in the pancreas which is characterized by an increase in blood sugar or often referred to as hyperglycemia due to a decrease in the amount of insulin from the pancreas [2]. The most common type of diabetes mellitus is type 2 diabetes. Diabetes mellitus is associated with morbidity and mortality in community. In addition, diabetes mellitus is associated with chronic progressive damage to the main organs, and some other organs are also at risk of problems due to diabetes mellitus such as corneas [3].

Diabetes mellitus can be prevented by knowing the risk factors [4]. Risk factors for diabetes mellitus are divided into two, namely reversible and irreversible risk factors. First, irreversible risk factors include dietary patterns, daily living patterns (e.g. eating), sleep patterns, physical activity patterns and stress management. Second, irreversible risk factors include age, gender, and genetic family history/genetic factor of diabetes [5]. Risk factors for type 2 diabetes mellitus are genetic and environmental factors. Genetic factors consist of family history and ethnicity/race, while environmental risk factors include age, obesity, food/nutritional factors and lack of physical activity [6].

The prevalence of diagnosed type 2 diabetes was $8.6 \%$, representing 21.0 million adults in the United States. NonHispanic blacks were the highest prevalence of diagnosed type 2 diabetes. The estimated prevalence of diagnosed type 2 diabetes increased with age and decreased with higher levels of educational attainment [7]. Specific kinship patterns are associated with the incidence of type 2 diabetes [8]. Dietary/nutritional patterns are potential in estimating some effects. Sugar, fat and oil, drinks and fast food were highly consumed by diabetic patients in both genders, while some types of vegetables, roots, and tubers were less consumed (6.1\% and 3.3\%, respectively) [9]. Type 2 diabetes mellitus sufferers, $67 \%(\mathrm{n}=725)$ of respondents $(\mathrm{n}$ men $=419(57.79 \%)$ vs. women $\mathrm{n}=306(42.21 \%)$, respectively; $p$ > 0.01), had poor dietary habits [10]. Previous studies have different results. Some results showed that there was a relationship and vice versa. In 2019, people in Ledug, Kembaran, Banyumas, Indonesia, have administered 3 Chronic Disease Management programs (Prolanis), and about 600 of 12,000 Ledug villagers in total have become members. The percentage of people with diabetes mellitus has reached $50 \%$ of the total. It is believed that they have type 2 diabetes mellitus after being diagnosed by a doctor, and most of them do not pay attention to the risk factors associated with diabetes mellitus. Based on the problems, the purpose of this study was to investigate the relationship among respondents' characteristics, family history, and dietary patterns to the incidence of diabetes mellitus in Ledug, Kembaran, Banyumas, Central Java.

\section{Materials AND Methods}

A correlational analysis was applied to analyze relationship among variables. The variables in this study were family history, dietary patterns, and the incidence of 
showed a significant relationship between age and the incidence of diabetes mellitus ( $\mathrm{p}$-value of $0,000<0,05$ ). The contingency coefficient $(0,637)$ showed a strong relationship between age and the incidence of diabetes mellitus.

Respondents with primary education had a tendency for diabetes mellitus while respondents with tertiary education were not likely to have diabetes mellitus. The result showed a significant relationship between education and the incidence of diabetes mellitus ( $p$-value of $0,000<0,05$ ).

Unemployed respondents dealt with diabetes mellitus but employed respondents had a tendency for diabetes mellitus. The result showed a significant relationship between employment status and the incidence of diabetes mellitus ( $\mathrm{p}$ value of $0,04<0,05)$. The contingency coefficient $(0,130)$ showed a very weak relationship between employment status and the incidence of diabetes mellitus.

Respondents with a family history of diabetes mellitus could have diabetes mellitus, and they could also be free of diabetes mellitus. The result showed that there was no relationship between family history of diabetes mellitus and the incidence of diabetes mellitus ( $p$-value of $0,117>0,05$ ). The contingency coefficient $(0,071)$ showed a very weak relationship between family history of diabetes mellitus and the incidence of diabetes mellitus.

Respondents with dietary patterns leading to a risk of diabetes mellitus could have diabetes mellitus but they could also be free of diabetes mellitus. The result showed a significant relationship between dietary patterns and the incidence of diabetes mellitus ( $p$-value of $0,002<0,05$ ). The contingency coefficient $(0,142)$ showed a very weak relationship between diet and the incidence of diabetes mellitus (Table 3).
Most of diabetes mellitus respondents were in the category of elderly (41-65 years) (240 people, $100 \%)$, of primary education (160 people, 66,7\%), and of unemployed (141 people, 58,8\%) (Table 1). Besides, most of respondents did not have any family history of diabetes mellitus (192 people, 80\%), but their dietary patterns caused a risk of diabetes mellitus (71 people, $71,2 \%$ ) (Table 2).

Elderly respondents (41-64 years) were likely to suffer from diabetes mellitus while the adults (18-40 years) did not have a tendency for diabetes mellitus. The result

Table 1. Frequency distribution of diabetes mellitus respondents' characteristics

\begin{tabular}{lrrrr}
\hline \multirow{2}{*}{ Category } & \multicolumn{2}{c}{ Diabetics } & \multicolumn{2}{c}{ Non-Diabetics } \\
\cline { 2 - 5 } & Frequency & Percentage (\%) & Frequency & Percentage (\%) \\
\hline Age & 0 & 0.0 & 0 & 0.0 \\
Adolescence & 0 & 0.0 & 195 & 81.2 \\
Adult & 240 & 100.0 & 45 & 18.8 \\
Elderly & 240 & 100.0 & 240 & 100.0 \\
Total & & & \\
\hline
\end{tabular}




\begin{tabular}{lrrrr}
\hline Level of Education & & & & \\
Primary & 160 & 66.7 & 69 & 28.8 \\
Secondary & 74 & 30.8 & 11 & 4.6 \\
Higher & 6 & 2.5 & 160 & 66.7 \\
Total & 240 & 100.0 & 240 & 100.0 \\
\hline Employment Status & & & & \\
Unemployed & 141 & 58.8 & 171 & 71.2 \\
Employed & 99 & 41.2 & 69 & 28.8 \\
Total & 240 & 100.0 & 240 & 100.0 \\
\hline
\end{tabular}

Table 2. Frequency distribution of family history and dietary patterns of diabetes mellitus respondents

\begin{tabular}{|c|c|c|c|c|}
\hline \multirow{3}{*}{ Category } & \multicolumn{2}{|c|}{ Diabetics } & \multicolumn{2}{|c|}{ Non-Diabetics } \\
\hline & & & & \\
\hline & Frequency & Percentage (\%) & Frequency & Percentage $(\%)$ \\
\hline \multicolumn{5}{|l|}{ Family history } \\
\hline No & 192 & 80.0 & 205 & 85.4 \\
\hline Yes & 48 & 20.0 & 35 & 14.6 \\
\hline Total & 240 & 100.0 & 240 & 100.0 \\
\hline \multicolumn{5}{|l|}{ Dietary patterns } \\
\hline No risk of diabetes & 69 & 28.8 & 102 & 42.5 \\
\hline Risk of diabetes & 171 & 71.2 & 138 & 57.5 \\
\hline Total & 240 & 100.0 & 240 & 100.0 \\
\hline
\end{tabular}

Table 3. The Relationship among respondents' characteristics (age, level of education, employment status), family history, and dietary patterns to the incidence of diabetes mellitus

\begin{tabular}{|c|c|c|c|c|c|c|c|c|}
\hline \multirow[b]{2}{*}{ Category } & \multicolumn{2}{|c|}{ Non-Diabetics } & \multicolumn{2}{|c|}{ Diabetics } & \multicolumn{2}{|c|}{ Total } & \multirow[b]{2}{*}{$\rho$ value } & \multirow[b]{2}{*}{$\mathrm{CC}$} \\
\hline & $\mathbf{F}$ & $\%$ & $\mathbf{F}$ & $\%$ & $\mathbf{F}$ & $\%$ & & \\
\hline Age & & & & & & & 0.000 & 0.637 \\
\hline Adolescence & 0 & 0.0 & 0 & 0.0 & 0 & 0.0 & & \\
\hline Adult & 195 & 40.6 & 0 & 0.0 & 195 & 40.6 & & \\
\hline Elderly & 45 & 9.4 & 240 & 50 & 285 & 59.4 & & \\
\hline Total & 240 & 50 & 240 & 50 & 480 & 100.0 & & \\
\hline Level of Education & & & & & & & 0.000 & - \\
\hline Primary & 69 & 14.4 & 160 & 33.3 & 229 & 47.7 & & \\
\hline Secondary & 11 & 2.3 & 74 & 15.4 & 85 & 17.7 & & \\
\hline Higher & 160 & 33.3 & 6 & 1.2 & 166 & 34.6 & & \\
\hline Total & 240 & 50 & 240 & 50 & 480 & 100.0 & & \\
\hline Employment Status & & & & & & & 0.04 & 0.130 \\
\hline Unemployed & 171 & 35.6 & 141 & 29.4 & 312 & 65 & & \\
\hline Employed & 69 & 14.4 & 99 & 20.6 & 168 & 35 & & \\
\hline Total & 240 & 50.0 & 240 & 50.0 & 480 & 100.0 & & \\
\hline Family history & & & & & & & 0.117 & 0.071 \\
\hline No & 205 & 42.7 & 192 & 40.0 & 397 & 82.7 & & \\
\hline Yes & 35 & 7.3 & 48 & 10.0 & 83 & 17.3 & & \\
\hline Total & 240 & 50.0 & 240 & 50.0 & 480 & 100.0 & & \\
\hline Dietary patterns & & & & & & & 0.002 & 0.142 \\
\hline No risk of diabetes & 102 & 21.2 & 69 & 14.4 & 171 & 35.6 & & \\
\hline Risk of diabetes & 138 & 28.8 & 171 & 35.6 & 309 & 64.4 & & \\
\hline Total & 240 & 50 & 240 & 50 & 480 & 100.0 & & \\
\hline
\end{tabular}




\section{DISCUSSION}

\section{A. The Relationship between Age and Diabetes Mellitus}

The results showed that elderly respondents (41-64 years) were likely to suffer from diabetes mellitus while the adults (18-40 years) did not have a tendency for diabetes mellitus. Age had a relationship with the incidence of diabetes mellitus ( $\rho$ value $0,000<0,05)$. The contingency coefficient $(0,637)$ showed a strong relationship between age and the incidence of diabetes mellitus. The result showed that most of diabetes mellitus respondents was elderly (4165 years) (240 people, $100 \%)$.

In line with Kurniawaty's research (2016), age increases the incidence of type 2 diabetes mellitus. People aged $\geq 45$ years could have 9 times risk of type 2 diabetes mellitus compared to those aged less than 45 years and it was statistically significant ( $\mathrm{p}$-value $=0,000$ and odds ratio/ OR of 9.3) [13]. Nur et. al. (2017) mentioned that chances of developing diabetes increase up to 2,16 times greater especially for people aged $>50$ years [14]. Referring to Trisnawati's research (2013), people aged $\geq 50$ could develop the incidence of type 2 diabetes mellitus because aging causes decreased insulin sensitivity and decreased body function for glucose metabolism [15].

The risk of having diabetes mellitus up to 4,568 times increases as people age compared to younger people. Age has a big role in the incidence of diabetes mellitus. As age increases, the ability of tissues to take blood glucose decreases so that the possibility of developing diabetes mellitus increases [16]. Age is a major factor in the increase in diabetes prevalence and impaired glucose tolerance. It is also stated that age is a factor in adults in which increasing age can decrease the ability of tissues to take blood glucose. This disease is more common in people aged over 40 years than in younger people [5].

On the other hand, Nur's research (2016) stated that most diabetic patients under 46 years old were included in adults. This research showed that there was a shift in the age of diabetes mellitus [17]. Diabetes mellitus can occur at a younger age (under 46 years). In her research, people aged $20-59$ years were at risk of diabetes mellitus $(8,7 \%)[18]$.

\section{B. The Relationship Between Level of Education \\ and Diabetes Mellitus}

The results showed that respondents with primary education had a tendency to develop diabetes mellitus while respondents with tertiary education did not have diabetes mellitus. Therefore, education had a significant relationship with the incidence of diabetes mellitus ( $\rho$-value $0,000<$ 0,05 ). The result showed that most of respondents were in primary education of 160 people $(66,7 \%)$. It indicates that respondents have less information about the factors and prevention of diabetes mellitus.

In line with Handayani's research (2018), 94\% of respondents with type 2 diabetes mellitus were in the lower education [19]. Gandini (2015) stated that there were $64 \%$ of diabetes mellitus patients with secondary education. This relates to one's level of understanding of the illness and its prevention [20]. Pradana (2015) explained that most diabetes mellitus patients with lower education are not compliant with the pharmacological therapy of diabetes mellitus [18].

On the contrary, Nur's research (2016) revealed that there was no significant relationship between education and blood glucose levels in patients with diabetes mellitus. The result showed that most of diabetes mellitus patients were in secondary education. The level of education does not directly affect the onset of diabetes mellitus. However, it affects dietary patterns/food selection [14].

\section{The Relationship between Employment Status and Diabetes Mellitus}

The results showed that unemployed respondents could suffer from diabetes mellitus. Employment status had a significant relationship with the incidence of diabetes mellitus ( $\rho$ value $0,04<0,05$ ). The contingency coefficient $(0,130)$ showed a very weak relationship between employment status and the incidence of diabetes mellitus. The result showed that most of respondents were unemployed (141 people, $58,8 \%$ ).

In line with Mahmud's research (2017), it is found that there was a significant relationship between employment status and diabetes mellitus [21]. Unlike Mahmud's research, Nur (2016) argued that there was no significant relationship between employment status and blood glucose levels in patients with diabetes mellitus [14]. In reference to Isnaini's research (2018), there was no significant relationship between employment status and the incidence of diabetes mellitus. The variables of occupations were related to physical activities and sports. Unemployed people (e.g. housewives) do some activities at home such as washing, cooking, cleaning the house and doing many other activities that require energy [22].

Those who do not work (e.g. housewives, unemployment, and retirees) can reduce their physical activity patterns. Unemployed people have lack of body movements and can be a trigger for obesity. This will cause insulin resistance. This situation causes body tissues less sensitive to the effects of insulin. Thus, sugar in the blood is not allowed to leave blood and enter cells [23].

\section{The Relationship Between Family History and \\ Diabetes Mellitus}

The results showed that respondents with a family history of diabetes mellitus were not likely to have diabetes mellitus. In this case, a family history of diabetes mellitus had no relationship with the incidence of diabetes mellitus ( $\rho$ value $0,117>0,05)$. The result showed that most of respondents (192 people, $80 \%$ ) did not have a family history of diabetes mellitus.

In line with Fadila's research (2016), 51\% of female patients with type 2 diabetes mellitus in Kardinah Regional Hospital did not have biological families with a history of diabetes mellitus [24]. Along with Nuraini's research (2016), 
the result showed that there was no relationship between family medical history and type 2 diabetes mellitus [25]. Wardiah (2018) stated that diabetes mellitus can occur in individuals who have a family history of diabetes, but it does not rule out the possibility for individuals who have no family history. About 3,264 times, family history could have an influence on the incidence of diabetes mellitus. This can be stated that individuals who have no family history are able to maintain their lifestyles to avoid the incidence of diabetes mellitus [16].

Some respondents admitted that maintaining diabetes treatment is not easy. As mentioned by Nugroho (2017), the level of stress experienced by people with diabetes mellitus can be caused by changes in both physical and psychological. Stress that is accompanied by other emotional attitudes has an impact on the compliance or noncompliance with the management of diabetes mellitus treatment. It describes that the higher the stress levels, the more emotional problems experienced by people with diabetes mellitus. This condition is related to patients with diabetes mellitus who have poor adherence to the treatment, thus, their blood sugar levels tend to increase [26].

As mentioned by Meidikayanti (2017), co-morbidities and family support also matter. It is found that there was a significant relationship between complications and family support with the quality of life of type 2 diabetes mellitus patients. It is assumed that complications affect mental and physical health of patients with type 2 diabetes mellitus. Therefore, it is believed that family support can increase patient motivation to recover. Family support generally consists of four dimensions, namely the emotional dimension, the instrumental dimension, the appreciation dimension, and the informational dimension. Among these four dimensions, the informational dimension needs to be considered because people with diabetes mellitus still do not know the implementation properly and the management of diabetes mellitus, moreover the awareness of family members to provide new information about diabetes mellitus is also necessary [27].

Unlike previous researchers, Etika (2016) stated that there was a relationship between family history of diabetes and the incidence of diabetes mellitus. People who have a family history of diabetes mellitus are more at risk than people who have no family history of diabetes mellitus [28]. Having the same idea, Kurniawaty (2016) explained that people with a family history of diabetes mellitus are more at risk than people without a family history of diabetes mellitus [13]. Type 2 diabetes mellitus is an inherited disease. Having a parent with diabetes mellitus increases 2 times risk of diabetes mellitus, and the risk can increase up to 6 times if people have parents with diabetes. Estimates for the heritability of type 2 diabetes mellitus range between 25 $40 \%$ [29].

Wardiah (2018) stated that having a family history could have 3,264 times risk of diabetes mellitus compared to those having no family history. A person is likely to have diabetes mellitus due to heredity. This happens because one of his family members (parents, grandfather, grandmother, uncle, aunt, and relatives) has diabetes mellitus. Heredity is not the only cause of diabetes mellitus, yet the connection between heredity and environmental factors is extremely important [16].

\section{E. The Relationship Between Dietary Patterns and \\ Diabetes Mellitus}

The results showed that respondents having dietary patterns at risk of diabetes had a tendency to develop diabetes mellitus. Dietary patterns had a significant relationship with the incidence of diabetes mellitus ( $\rho$ value $0,002<0,05)$. The contingency coefficient $(0,142)$ showed a very weak relationship between dietary patterns and the incidence of diabetes mellitus. The data showed that most respondents had dietary patterns at risk of diabetes mellitus (171 people, $71,2 \%$ ), and a lot of respondents often consumed carbohydrate foods.

In line with the research of Dolongseda (2017), patients with type 2 diabetes mellitus had good dietary patterns (29 respondents, 38,7\%) and bad dietary patterns (46 respondents, 61,3\%) [30]. Besides, Nuraini (2016) explained that there was a relationship between dietary patterns and type 2 diabetes mellitus [25]. Hariawan (2014) also stated that most respondents with type 2 diabetes mellitus had unhealthy dietary patterns leading to the risk factors in the incidence of diabetes mellitus [31]. Gillani (2018) also mentioned that uncontrolled eating behavior showed a significant effect on type 2 diabetes mellitus $(p=0,001)$ [10].

Researchers at Rutgers believe that high levels of fructose consumption have a supportive relationship for the development of type 2 diabetes mellitus. There is no doubt that nutrition is an important factor in the onset of type 2 diabetes mellitus. A healthy and balanced daily diet need to be considered to maintain ideal body weight. An appeal for balanced nutrition helps to prevent various diseases including preventing or slowing the onset of diabetes mellitus [32].

Wardiah (2018) mentioned that people with dietary patterns more than 2.758 times could be at risk of having diabetes mellitus compared to those with adequate or less dietary patterns. Dietary patterns are useful to control the amount and type of food to maintain health. Dietary patterns as one of the irreversible risk factors are closely related to diabetes mellitus. People who cannot control their dietary patterns will be more susceptible to disease than those who are careful in consuming food. Excessive eating can cause sugar and fat in the body accumulating excessively thereby increasing the risk of developing diabetes mellitus. The recommended amount of carbohydrates for people with diabetes mellitus is $45-68 \%$ of the total calories in the diet [16].

Regulating dietary patterns such as a healthy diet with balanced nutrition, is very important to control blood sugar, whereas people with diabetes mellitus still like consuming sweet foods or drinks. Regulating carbohydrate intake is also important for diabetes mellitus patients, and the recommended carbohydrate foods are foods containing fiber. In consuming foods, several things should be considered; the 
[2] A. D. Association, -Diagnosis and classification of Diabetes Mellitus, „| 2012. [Online]. Available: https://care.diabetesjournals.org/content/35/Supplem ent_1/S64.

[3] K. C. Shih, K. S.-L. Lam, and L. Tong, -A Systematic Review on the impact of Diabetes Mellitus on the ocular surface,\|J. Nutr. Diabetes, 2017.

[4] K. K. R. Indonesia, -Petunjuk teknis pengukuran faktor risiko Diabetes Mellitus, in Petunjuk Teknis Pengukuran Faktor Risiko Diabetes Mellitus, 2010.

[5] I. P. Suiraoka, Penyakit degeneratif. 2012.

[6] M. J. Gibney, B. M. Margetts, J. M. Kearney, and L. Arab, Gizi kesehatan masyarakat. Jakarta: EGC, 2009.

[7] K. M. Bullard et al., - Prevalence of diagnosed diabetes in adults by diabetes type - United States, 2016,\|MMWR. Morb. Mortal. Wkly. Rep., vol. 67, no. 12, pp. 359-361, 2018.

[8] B. G. Kral et al., - The relationship of family history and risk of type 2 diabetes differs by ancestry, Elsevier Masson SAS, vol. 45, no. 3, pp. 261-267, 2019.

[9] S. Chakravorty, -Food consumption pattern of diabetic patients: hospital based study, J. Curr. Sci., vol. 20, no. 1, 2019.

[10] S. W. Gillani, M. I. M. Abdul, I. A. Ansari, H. A. Zaghloul, S. Ata-ur-Rehman, and M. R. Baig, - Predicting relationship of eating behavior, physical activity and smoking with type II diabetes and related comorbidities among Saudi citizens: crosssectional observational study, Int. J. Diabetes Dev. Ctries., vol. 39, no. 1, pp. 115-122, 2019.

[11] S. Notoatmodjo, Metodologi penelitian kesehatan. Jakarta: Rineka cipta, 2010.

[12] Sugiyono, Metode penelitian kuantitatif, kualitatif dan $R \& D$. Bandung: Alfabeta, 2011.

[13] E. Kurniawaty and B. Yanita, -Faktor-Faktor yang berhubungan dengan kejadian Diabetes Melitus tipe II,॥ J. Major., vol. 5, no. 2, pp. 27-31, 2016.

\section{CONCLUSION}

This study revealed that there was a relationship between respondents' characteristics (age, level of education, employment status) and dietary patterns to the incidence of diabetes mellitus. However, there was no relationship between family history and diabetes mellitus. Health workers should provide appropriate information and education to the community about diabetes mellitus such as improving lifestyles, managing dietary patterns, and exercising regularly. Taking regular diabetes mellitus screening checks is also important.

\section{REFERENCES}

[1] K. K. B. P. dan P. Kesehatan, -Hasil utama Riskesdas 2018,\| 2018.
[14] A. Nur, E. Fitria, A. Zulhaida, and S. Hanum, -Hubungan pola konsumsi dengan Diabetes Melitus tipe 2 pada pasien rawat jalan di RSUD Dr. Fauziah

Bireuen Provinsi Aceh,\| Media Penelit. dan Pengemb. Kesehat., vol. 26, no. 3, pp. 145-150, 2017.

[15] S. Trisnawati, T. Widarsa, K. Suastika, S. Trisnawati, T. Widarsa, and K. Suastika, -Laporan hasil penelitian faktor risiko Diabetes Mellitus tipe 2 pasien rawat jalan di Puskesmas Wilayah Kecamatan Denpasar Selatan,\| Fakt. Resiko Diabetes Mellit. Tipe 2 Pasien Rawat Jalan Puskesmas Wil. Kec. Denpasar Selatan, vol. 1, no. 1, pp. 1-6, 2013. 
[16] Wardiah and E. Emilia, -Faktor risiko Diabetes Mellitus pada wanita usia reproduktif di Wilayah Kerja Puskesmas Langsa Lama Kota Langsa, Aceh,॥ J. Kesehat. Glob., vol. 1, no. 3, pp. 119-126, 2018.

[17] A. Nur, V. Wilya, and R. Ramadhan, -Kebiasaan aktivitas fisik pasien Diabetes Mellitus terhadap kadar gula darah di Rumah Sakit Umum dr. Fauziah Bireuen,\| Sel J. Penelit. Kesehat., vol. 3, no. 2, pp. 41-48, 2017.

[18] I. P. A. Pradana, -Hubungan karakteristik pasien dengan tingkat kepatuhan dalam menjalani terapi Diabetes Mellitus di Puskesmas Tembuku 1 Kabupaten Bangli Bali, $I S M$, vol. 8, no. 1, pp. 1-5, 2015.

[19] S. T. Handayani, Hubaybah, and D. Noerjoedianto, - Hubungan obesitas dan aktivitas fisik dengan kejadian Diabetes Mellitus tipe II di Wilayah Kerja Puskesmas Olak Kemang Tahun 2018,\| J. Kesmas Jambi, vol. 2, no. 1, pp. 1-11, 2018.

[20] A. Lis, A. Gandini, E. Pranggono, and H. Ropi, -Pengaruh pendidikan kesehatan terhadap pengetahuan, perilaku dan gula darah,\| vol. III, no. 9, pp. 474-482, 2015.

[21] F. R. Mahmud and N. A. Sudirman, -Faktor-faktor yang berhubungan dengan penyakit Diabetes Mellitus di Ruang Poli Interna RSUD Mokopido Kabupaten Tolitoli,॥ no. Dm, pp. 168-175, 2017. [22] N. Isnaini and R. Ratnasari, -Faktor risiko mempengaruhi kejadian Diabetes Mellitus tipe dua,\|J. Kebidanan dan Keperawatan Aisyiyah, vol. 14, no. 1, pp. 59-68, 2018.

[23] D. M. Nathan and L. M. Delahanty, Menaklukan Diabetes. Jakarta: Gramedia, 2009.

[24] N. A. Fadilah, L. D. Saraswati, and M. S. Adi, -Gambaran karakteristik dan faktor-faktor yang berhubungan dengan kejadian Diabetes Mellitus Tipe 2 pada wanita (Studi di RSUD Kardinah Kota Tegal),॥ vol. 4, pp. 176-183, 2016.

[25] H. Y. Nuraini and R. Supriatna, - Hubungan pola makan, aktivitas fisik dan riwayat penyakit keluarga terhadap Diabetes Melitus tipe 2,\| J. Ilmu Kesehat. Masy., vol. 5, no. 1, pp. 5-14, 2017.

[26] S. A. Nugroho and O. S. Purwanti, - Hubungan antara tingkat stres dengan kadar glukosa darah pada pasien Diabetes Melitus di Wilayah Kerja Puskesmas Sukoharjo I Kabupaten Sukoharjo,\|Publ. Ilm. Ums, pp. 43-51, 2013.

[27] W. Meidikayanti and C. Umbul, - Hubungan dukungan keluarga dengan kualitas hidup Diabetes Melitus tipe 2 di Puskesmas Pademawu,\| J. Berk. Epidemiol., vol. 5, no. August, pp. 240-252, 2017.

[28] A. N. Etika and V. Monalisa, -Riwayat penyakit keluarga dengan kejadian Diabetes Mellitus, $\| J$. care, vol. 4, no. 1, pp. 34-41, 2016.
[29] J. L. Vassy et al., - Association between parental history of diabetes and type 2 diabetes genetic risk scores in the PPP-Botnia and Framingham Offspring Studies,\|NCBI, 2011.

[30] F. F. Dolongseda, G. N. M. Masi, and Y. B. Bataha, - Kadar gula darah pada pasien Diabetes Melitus,॥ vol. 5, 2017.

[31] H. Hariawan, A. Fathoni, and D. Purnamawati, -Hubungan gaya hidup (Pola makan dan aktivitas fisik) dengan kejadian Diabetes Mellitus di Rumah Sakit Umum Provinsi NTB,\| J. KEPERAWATAN TERPADU (INTEGRATED Nurs. JOURNAL), vol. 9698, 2013.

[32] S. Yulianto, Makanan berbahaya untuk diabetes. Kesehat. Masy. Indones., pp. 211-218, 2014. Jakarta, 2014.

[33] A. M. Idris, N. Jafar, and R. Indriasari, —Diet and aktivitas fisik dengan kejadian Diabetes Mellitus blood sugar levels of type $2 \mathrm{DM}$ patient

[34] K. Wandansari, - Hubungan pola makan dan, $J$. Media tipe 2 di RSUD dr. Moewardi Surakarta,\| 2013. 